\title{
Revitalizing Home Economics Education in Tertiary Institutions in Nigeria Through ICT Use for Skill Acquisition for Global Relevance
}

\author{
Juliana Ego Azonuche
}

\author{
Department of Vocational Education, \\ Delta State University, Abraka, Nigeria
}

DOI: https://doi.org/10.36941/jesr-2020-0131

\begin{abstract}
The study examined how to revitalize Home Economics education in tertiary institutions through ICT use for skill acquisition and global relevance. Three research questions and one hypothesis guided the study. A descriptive survey was adopted for this study. 233 Lecturers and students constituted the population and 134 subjects were selected through simple random sampling method. A structured questionnaire was used to collect data and was analysed using mean, standard deviation and t-test analysis. Findings showed 30 skills that can be acquired through ICT use in Home Economics teaching and learning, such as; scaling of foods, meal planning, budgeting, selection, purchasing of foodstuffs and preparation. Factors affecting teaching and learning Home Economics include; insufficient personnel to teach practical, teaching more of theory than practical in the course. 10 ways proffered on how to revitalize Home Economics education include; equipping laboratory with adequate ICT facilities, teachers and students being ICT proficient, Carrying out assignment online, among others. It was concluded that since much skills can be learnt in Home Economics that enables learners to be relevant to self and the world, training and provision of ICT equipment is important in tertiary institutions.
\end{abstract}

Keywords: Home Economics Education; Information and Communication Technology; Skill Acquisition; Global Relevance

\section{Introduction}

It has been of great concern to employers of labour the quality and calibre of graduates being rolled out every year from tertiary institutions in Nigeria due to poor skill acquisition for the jobs. Home Economics is a subject with skill-oriented aimed at helping students to acquire skills for jobs after graduation and be relevant to self and society at large. The role of saleable Home Economics skills in tackling the myriad problems of present-day society cannot be overemphasized.

Home Economics subject deals with individuals, families, communities and environment, their relationships and interaction for a successful society. Anyakoha (2013) sees Home Economics as empowering life of families the education of persons for family life, promoting their goods and services as well as discovering through researches to maximize potentials, productivity and assisting people to adapt to changes and rearranging their future life.

The philosophy of Home Economics at the tertiary level boarders on preparing learners to be 
knowledgeable and competent in demonstrating right skills acquired for the job that he/she is expected to do (Federal Republic of Nigeria (FRN), 2004), thus, on a long run improving the quality of individual family lives and the larger society. Bamali (2013) stressed that Home Economics as a subject impact both practical and theoretical knowledge in art and science with the use of right technologies in education.

Egbiri and Chukwuedo (2013) noted that this type of education that equips the learner with needed skills and competencies bridge the gaps between the classroom and the real world and enables them to use the knowledge acquired for creativity, innovations and business ideas to carry out job activities well. It, therefore, becomes imperative to close the gap between classroom teaching and learning of Home Economics and needed skills in the world of work (Ejiofor \& Nawkile, 2016).

Home Economics education as practical skill course with global importance has many areas of specialization; such as Foods and nutrition, Clothing and textiles, Home management, Child development, among others. These areas are relevant in solving present-day problems of unemployment, through global technological advancement for occupational mobility. This can be achieved through information communication technology (ICT) use in teaching and learning Home Economics.

Information communication technology refers to the processes that entail acquiring, processing strong electronic gadgets by combining computer and other telecommunication like a satellite. Udoh (2010) regards ICT as various technologies to create, store, process, communicate and disseminate information for use. It includes the infrastructures used in these processes, their application and services rendered such as radio, television, computer, satellite, cables, optic fibre, phone, facsimile machine, network hardware and software, the various and applications associated with them like video conferencing and distance learning (Jongour, Mohammed \& Abba, 2008; Udoh, 2010). The importance of ICT in education and teachers' roles in usage is paramount in shaping the future of education in the country. (Udoh, 2010) the use of ICT process in Home Economics education can help to internalize knowledge, skills and promote relevance in globalization. World Bank (2013) recent policy reported ICTs as vital tools that globally transform the world of work, providing innovation opportunities for labour markets. Home Economics is moving with the times of globalization, using ICT in the course can help to obtain needed information from the internet to enhance teaching and learning for skill acquisition Sadker and Sadker (2003) observed that student lectures can be presented with software to build and improve knowledge, work with others across the globe, explain concepts, work at one's own pace on preferred mode. Kwacha (2007) reiterated that the use of ICT in teaching and learning enhance flexible interaction of individual engaging dynamic content study by providing a means of individualized instruction, speed, deeper acquisition of skills through students' involvement, in the learning process.

ICT can effectively be used in Home Economics education through virtual teaching (video conferencing), web-based teaching and learning through internet and world wild web (www), which are utilized as the major instructional resource in tertiary institutions, slides and tutorial (audio) and computer-assisted instruction inclusive, all these provide the teacher and learners ready materials which can be stored and retrieved where needed ideas are exchanged for the greater initiative, creativeness, and skill acquisition.

Skill refers to someone ability to carry out activities effectively. Skills are acquired aforetime by the ability to utilize and control thinking and attitudes in a given task being performed. The use of ICT in teaching and learning skills can be acquired in food and Nutrition on proper food handling, hygiene and safety. Students could learn new recipes and products in the food industry, visual slides, audio tapes/CD, television and radio discussion on meal planning, food budgeting and purchasing, meal preparation method, food preservation, food poisoning, nutritional diseases management strategies and nutritional trend (Uko-Aviomoh, 2006).

Okoh and Azonuche (2010) highlighted the internet; cables, Facebook, fashion web, among others as ICT tools to keep in line with fashion learn to take body measurement, draft a pattern and sew clothes. Iyere and Orunwense (2007) emphasized that clothing and textiles equip students with 
reasonable skills needed to meet family global clothing needs. Hence skill can be acquired through ICT use in wardrobe planning and selection, clothing maintenance and production, interior decoration, event decoration, housing design, among others in Home management. These relevant skills are learnt in home Economics courses studied in tertiary institution to achieve the objectives. The acquisition of these skills makes learner globally relevant as they are acquainted with information round the globe beyond their immediate environment. This promotes education beyond the classroom for self-reliance and sustainable growth and development.

Tertiary institutions are all level of post-secondary education such as Universities, Polytechnics, Monotechnics and College of education. (FRN 2013). Home Economics education at this tertiary level provides intellectual reliance, national development and global competitiveness. Despite these parts played by Home economic education evident shows that the rate of unemployment is high in Nigeria. National Bureau of Statistics (NBS) (2016) report for the second quarter of 2016 indicated the unemployment rate at $13.3 \%$ which is about 26.6 million people.

The enrolment of Home Economics has been very low due to poor public perception (Anyakoha, 2013). Agbaegbu (2011) observed the emphasis on theory teaching in the university more than practical skill training needed for competency and relevance. Hence, there is need to use ICT in teaching and learning to revitalize Home Economics education for skill development for self, national and global relevance.

Revitalizing refers to bringing something to life, invigorating new life. Therefore, revitalizing Home Economics education involves strengthening the programmes to be more active, attractive and impactful to learners and others alike. This ICT use can achieve by inculcating various world marketable skills in both the lecturers and students to compete with their counterparts. There have been recently in the global arena areas, opportunities, developmental growth in all areas of life; issues of threat, challenging situation, global market competition, among others (Anyakoha 2013). There are knowledge explosion and expansion, technological growth and development in the society.

The relevance of Home Economics in promoting productivity and maintaining competitiveness globally cannot be overemphasized. Abanyam, Edeh and Abanyam (2016) stressed the increasing joblessness among graduates who supposed to create jobs for themselves and other persons alike. The goal in National Policy on Education for tertiary institutions to give train and impact desirable skills to persons to be relevant and reliant, this, Joe (2019) stated can be achieved through teaching more desirable practical skills that are relevant to meet the yearning of the competitive present labour workforce market.

Home economics has not been embraced as a tool for creating jobs and national development. The graduates are still not employed either by the government, private organizations or be self-reliant due to the way the courses are being taught so they lack adequate skills. This problem Anyakoha (2013) decried is because the emphasis is more on theoretical teaching than practical in schools. Students are not exposed to ICT use in teaching and learning Home economics to be abreast with adequate information, knowledge and current global trend, innovations and changes. The challenges of not teaching enough practical as observed are due to learners' poor knowledge in ICT, lack of ICT infrastructure/equipment, fund and interest the course, among others. Effective and adequate implementation of Home Economics education must recognize the use of ICT in teaching and learning to expose lecturers and students to up to date information, skills and knowledge relevant to self and benefit to the larger world. Therefore, this study is directed towards revitalizing Home Economics Education through ICT use for skill acquisition and global relevance.

\subsection{Purpose of the Study}

The main purpose of this study was to examine how to revitalize Home Economics education in the tertiary institution through ICT use for skill acquisition and global relevance. Specifically, the study sought to:

1. ascertain skills that can be acquired through ICT use in Home Economics education in 
Tertiary Institution for global relevance;

2. identify factors that impede Home Economics education for Skill acquisition in a tertiary institution;

3. determine ways to revitalize Home Economics education through ICT use for skill acquisition and global relevance.

\section{$1.2 \quad$ Research Questions}

1. What are the skills that can be acquired through ICT use in Home Economics education in tertiary institutions for global relevance?

2. What are the factors that impede skill acquisition in Home Economics education in a tertiary institution for global relevance?

3. In what ways can Home Economics education be revitalized through ICT use in tertiary institutions for global relevance?

\subsection{Hypothesis}

There is no significant difference in the mean responses of Lecturers and Students on the skills that can be acquired in Home Economics education through ICT use in tertiary institutions for global relevance.

\section{Research Methods}

The study design employed was a descriptive survey which enables the respondents through a questionnaire to give their personal opinions about the problem under investigation for generalization. The study area was Delta State, Nigeria.

The study population constituted all the students and lecturers of Home Economics in all tertiary institutions that undertake Home Economics education programmes. It is 233 subjects comprising of 35 lecturers and 198 students. "

A sample size of 134 was selected with a simple random sampling technique. Three institutions were randomly selected out of five that offer Home Economics in the state. These are Delta State University: 7 Lecturers and 29 students, Federal College of Education (Technical) Asaba; 10 lecturers and 45 students and College of Education Warri; 35 students and 8 lecturers. All the subjects were used because the sample size is small.

A structured questionnaire was used to collect data developed from the purpose of the study and literature reviewed, titled Revitalizing Home Economics Education through ICT for Skill Acquisition (RHEEICTSA). The questionnaire was on a 4-point rating scale of Strongly Agreed (SA) =4, Agreed (A) $=3$, Disagreed $(D)=2$, and Strongly Disagreed $(S D)=1$. Section A contained demographic information of the subjects while $\mathrm{B}$ contained items for responses from the subjects.

The instrument was face validated by two Home Economics Lecturers and one lecturer in test and measurement, all from the University of Nigeria Nsukka. Their constructive corrections were affected for the final items. 20 respondents were used to carry out a pilot study to determine the reliability of the questionnaire. Test-retest was used to ascertain internal consistency, computed with Cronbach alpha and coefficient obtained was 0.83

\subsection{Method of Data Collection and Analysis}

The questionnaire was administered to 134 subjects with the help of three research assistants, all were filled and retrieved. Data were analysed with mean, standard deviation for research questions. 2.50 was used as a mean cut off point. Items with mean $2.50-4.00$ were accepted as strongly agreed while $0.1-2.49$ were regarded as strongly disagreed. t-test was used to analyse the hypothesis at 0.05 level of significance 


\section{Result}

3.1 Research Question 1: What are the skills that can be acquired through ICT use in Home Economics education in a tertiary institution for global relevance?

Table 1: Mean rating of responses on skills that can be acquired through ICT use in Home Economics education in a tertiary institution

\begin{tabular}{|c|c|c|c|c|}
\hline S/No & Areas of Skill Acquisition in Home Economics & $\overline{\mathbf{X}}$ & SD & Remark \\
\hline & Through ICT Use & & & \\
\hline & Foods \& Nutrition & & & \\
\hline 1 & Weighing and scale measurement of food & 3.00 & 0.62 & SA \\
\hline 2 & Meal planning processes & 2.78 & 0.90 & SA \\
\hline 3 & Meal preparation methods & 3.01 & 0.64 & SA \\
\hline 4 & Meal Service types & 3.01 & 0.78 & SA \\
\hline 5 & Correct use of kitchen equipment/utensils & 2.83 & 0.84 & SA \\
\hline 6 & Budgeting, selection and purchasing of foodstuffs & 2.68 & 0.78 & SA \\
\hline 7 & Foods for entertainments & $3 \cdot 53$ & 0.69 & SA \\
\hline 8 & Foods and kitchen hygiene & 2.70 & 0.82 & SA \\
\hline 9 & Safety in food handling & 2.99 & 0.73 & SA \\
\hline 10 & Cake making and design & 3.71 & 0.69 & SA \\
\hline 11 & Development of recipe and testing & 3.43 & 0.71 & SA \\
\hline 12 & Methods of food preservation & 2.71 & 0.66 & SA \\
\hline \multirow[t]{2}{*}{13} & Management of nutritional disorder & 3.24 & 0.99 & SA \\
\hline & Clothing and Textiles & & & \\
\hline 14 & Development and production of apparels & 3.08 & 0.99 & SA \\
\hline 15 & Designs and fashion in clothing & 3.71 & 0.68 & SA \\
\hline 16 & Making of stitches and seams & 3.12 & 0.72 & SA \\
\hline 17 & Use of clothing accessories & 2.08 & 0.84 & SA \\
\hline 18 & Clothing design sketching and illustrations & 2.79 & 0.70 & SA \\
\hline 19 & Fitting of clothing & 3.00 & 0.88 & SA \\
\hline 20 & Taking body measurements & 3.41 & 0.72 & SA \\
\hline 21 & Pattern drafting, alteration and adaptation & $3 \cdot 38$ & 0.90 & SA \\
\hline 22 & Tie and dye/batik production & 3.71 & 0.67 & SA \\
\hline 23 & Crochet and Knitting & 3.69 & 0.61 & SA \\
\hline 24 & Embroidering of clothes & 3.70 & 0.75 & SA \\
\hline \multirow[t]{2}{*}{25} & Colour combination in clothing & $3 \cdot 58$ & 0.84 & SA \\
\hline & Home Management & & & \\
\hline 26 & Interior decoration and colour harmony & 2.81 & 0.90 & SA \\
\hline 27 & Use of Curtains and draperies & 2.90 & 0.72 & SA \\
\hline 28 & Housekeeping & 2.58 & 0.81 & SA \\
\hline 29 & Clothing Maintenance & 3.00 & 0.65 & SA \\
\hline 30. & Laundry and dry cleaning & 3.15 & 0.76 & SA \\
\hline
\end{tabular}

Keys: $\overline{\mathrm{X}}$-Mean SD - Standard Deviation

Table 1 shows that all the items had a range of mean value from $2.58-3.71$ which fall in the category of strongly agreed. This shows that the items are the areas of skill acquisition in Home Economics education through ICT use in a tertiary institution. Standard deviation ranged from $0.61-0.99$ indicating closeness in responses. 
3.2 Research Question 2: What are the factors that impede skill acquisition in Home Economics education in tertiary institutions?

Table 2: Mean rating of responses on factors that impede skill acquisition in Home Economics Education in Tertiary Institution.

\begin{tabular}{clccc}
\hline S/No & Factors that Impede Skill Acquisition & $\overline{\mathbf{X}}$ & SD & Remark \\
\hline 1 & Lack of enough practical demonstrations & 3.00 & 0.80 & SA \\
2 & Obsolete equipment and tools & 3.88 & 0.88 & SA \\
3 & Not having enough time for practical classes & 3.20 & 0.78 & SA \\
4 & Lectures are more of theory learning & 3.01 & 0.92 & SA \\
5 & No money for practical teaching & 3.10 & 0.90 & SA \\
6 & Poorly equipped laboratory & 2.91 & 0.82 & SA \\
7 & The unfavourable attitude of school management towards this course & 3.21 & 0.82 & SA \\
8 & Lack of adequate lecturers in quality and number to carry out practical teaching & 3.80 & 0.73 & SA \\
9 & No individualized practical instructions & 3.11 & 0.86 & SA \\
10 & Poor attitude and interest of the students & 2.90 & 0.67 & SA \\
11 & Gender bias as it is often regarded only good for females & 2.86 & 0.74 & SA \\
\hline
\end{tabular}

Keys: $\overline{\mathrm{X}}$-Mean SD - Standard Deviation

Table 2 showed that all the items have to mean ranging between $2.86-23.88$ showing respondents opinion as strongly agreed. This shows that all the items are factors that impede skill acquisition in Home Economics education in a tertiary institution. Not much variance in their responses since standard deviation ranged from $0.67-0.92$

3.3 Research Question 3: In what ways can Home Economics education be revitalized through ICT use in tertiary institutions for skill acquisition and global relevance?

Table 3: Mean rating of responses on the ways Home Economics education can be revitalized through ICT use in a tertiary institution for skill acquisition and global relevance.

\begin{tabular}{|c|c|c|c|c|}
\hline S/No & Way of Revitalizing & $\overline{\mathbf{X}}$ & SD & Remark \\
\hline 1 & Lecturers should be trained to be ICT proficient & 3.17 & 0.68 & SA \\
\hline 2 & Students should be ICT compliance & 3.80 & 0.72 & SA \\
\hline 3 & Laboratories should be equipped with ICT facilities & 2.41 & 0.63 & SA \\
\hline 4 & Adequate light should be provided & 3.60 & 0.78 & SA \\
\hline 5 & Students should be given the opportunity to use ICT to practice what they learn & $3 \cdot 52$ & 0.89 & SA \\
\hline 6 & ICT should be sued for both theory and practical teaching activities & 3.62 & 0.61 & SA \\
\hline 7 & Lecturers and students should be encouraged to possess a personal computer for use & 3.80 & 0.68 & SA \\
\hline 8 & Working assignment with ICT online and submit with it & 2.85 & 0.78 & SA \\
\hline 9 & Giving incentives to students that perform well in practice. & 2.90 & 0.84 & SA \\
\hline 10 & $\begin{array}{l}\text { Make provision for lecturers and students to access other universities on-line database, } \\
\text { website and researches }\end{array}$ & 3.41 & 0.90 & SA \\
\hline
\end{tabular}

Keys: $\overline{\mathrm{X}}$-Mean SD - Standard Deviation

Table 3 shows at all the items mean rating ranged from $2.85-3.80$, this indicates that the item 2 s are ways of revitalizing Home Economics education in a tertiary institution for skill acquisition and global relevance which includes training lecturers on ICT, equipping laboratory with ICT facilities, use of ICT to teaching both practical and theory, doing assignment online, among others. Responses were not at variance as standard deviation is between $0.61-0.90$. 


\subsection{Hypothesis}

There is no significant difference in the mean responses of lecturers and students on the skills that can be acquired through ICT use in Home Economics education tertiary institution for global relevance.

Table 4: t-test analysis on the significant difference between responses of lecturers and students on the skills that can be acquired through ICT use

\begin{tabular}{|c|c|c|c|c|c|c|}
\hline Variable $\mathrm{N}$ & $\mathrm{X}$ & SD & DF & T-cal & T-table & Decision \\
\hline Lectures 25 & 12.15 & 2.92 & 132 & 0.83 & 1.96 & NS \\
\hline Students 109 & 20.60 & 3.05 & & & & \\
\hline
\end{tabular}

Table 4 shows that the t-calculated 0.83 is less than t-table of 1.96 , Hypothesis is retained. Therefore, there exists no significant difference between lecturers and students on the skills that can be acquired in Home Economic Education through ICT use in tertiary institutions.

\section{Discussion}

The finding of the study showed 30 areas of skills acquisition in Home Economic Education through ICT usage in a tertiary institution in Foods and nutrition, Clothing and textiles and Home Management which include; skills in measuring foods, selection and buying of food, meal planning, preparation and improving food value and managing the nutritional disorder, among others. Thus, findings agreed with the report of Anerua and Azonuche (2010) that computer can be used in diet and meal programmes, foodservice and generating food list options for different diet, select food combination and shopping information and plan meals. Uko-Aviomoh (2006) noted skills students can learn in foods and nutrition for business to include; ways of preparing foods, management of ailments and diseases using food nutritional trend in food use to be globally relevant and reliant and fit into the larger world. UkoAviomoh (2007) further buttressed that ICT can be used in Home Economics to keep abreast with fashion, fabric and style in apparel. The use of ICT in teaching Home Economic will make learning more concrete, precise, exciting, invaluable and relevant. Joe (2019) emphasized the need for sufficient practical skill teaching in some courses such as Home Economics so that the learners can be useful and participate in this $21^{\text {st }}$ century relevant job market competition. Ejinkeonye (2016) reported that utilizing of internet, computer and online information is currently advertising the educational system as the usage of ICT in education in globally in increase, facilitating knowledge gain, acquisition of relevant skills and competences.

Finding also showed that factors that impede skills acquisition in Home Economic education include lack of enough practical demonstrations, more emphasis on teaching theory than practical poorly equipped laboratory, no money for the practical, individualized practical class and lack of interest from students, among others. Thus, findings in line with Ejiofor and Nawkile (2016) who found that lack of fund and personnel for practical, less emphasis on the practical and poor attitude of students are factors affecting practical skill acquisition in vocational courses in a tertiary institution. Finding is so because Home Economics is a vocational course lack adequate personnel to carry out practical classes and otherwise may not be able to assess students practical for more instruction. Supporting, Baruah (2013) who emphasized that practical agricultural education programmes are hindered by personnel who are not adequate to guide the students in practical exposure.

Finding further showed that training lectures and students to be ICT compliance, equipping laboratory with adequate facilities for practical teaching and learning, personal computer possession by lecturers and students and improving access to other university website and database, giving incentives to excelling students and lecturers in ICT use, among others are the ways to revitalizing Home Economics education through ICT use for skill acquisition and global relevance. Thus, the finding supports Ejiofor and Nawkile (2016) who reported laying a more premium on teaching practical 
agriculture to boost image for societal acceptance and embrace. This is because many vocational courses suffer image problem due to more theory emphasis than practical which can boast skill possession, national, global development and relevance achieving set goals. Guma, Faruque, and Khushi (2013) noted ICT as one way of solving educational problems. Oviawe and Ojo (2010) stated that ICT use in accessing other libraries, research institutions, consulting technical vocational education stored files and agencies of the government for journals, bulletins, periodical newsletters on the internet. ICT enables teachers and learners to reach the world within the shortest possible time, breaking boundaries to acquire knowledge and skills for societal usefulness.

The finding showed that the mean responses on lectures do not significantly differ from the students on the skill that can be acquired in Home Economic Education through ICT use. This is due to the relevance of these skills in Home Economic education goal attainment in tertiary institutions in Nigeria. Supporting Ejinkonye (2016) opined that the use of ICT in teaching exposes both teachers and students to intensive practical activities for knowledge and skill impartation in learning processes.

\section{Conclusion}

The role of ICT in teaching Home Economics in schools is important because of the numerous relevant skills that can be acquired as a vocational area. Though same factors were identified to hinder skills development and possession in tertiary institutions, if put under check the measures enumerated such as adequate personnel and equipped laboratory with ICT facilities, revitalizing Home Economic Education for skill acquisition and global relevance will be achieved in tertiary institutions in Delta state.

\subsection{Recommendations}

The following recommendations are made based on findings:

1) Emphasis should be more on teaching and developing practical skills in tertiary institutions.

2) Practical demonstrations should be funded or subsidized by the government.

3) The image of Home Economic should be boasted by showcasing skills that can be acquired through ICT usage in teaching and learning by internet global linkages.

4) Workshops, training and seminars should be organized for lecturers and students from time to time update their ICT competencies.

\section{References}

Abanyam, F. E., Edeh, N. I., \& Abanyim, V. A. (2016). Repositioning technical vocational education and training (tvet) and entrepreneurship education for self-reliance in Nigeria. Journal of Association of Vocational and Technical Educator of Nigeria (JAVTEN), 21(2), 265-273.

Agbaegbu, T. (2011). Why unemployment is high in Nigeria. Newswatch magazine, pp..18-20 Jan $31^{\text {st. }}$

Anerua, F. A., \& Azonuche, J. D. (2010). Information communication technology: A necessary tool for foods and nutrition education, issues and challenges. Multidisciplinary Journal of Research Development, 15(4),49-55.

Anyakoha, E. U. (2013). Positioning vocational and technical education on the vanguard of sustainable economic development. A keynote address presented at the maiden conference of School of Vocational Education, Federal College of Education (Technical) Asaba, Delta State, Nigeria, on Vocational and Technical Education for Sustainable Economic and National Development $14^{\text {th }}-17^{\text {th }}$ May 2013.

Bamali, H. S. (2013). Competence and strategies for the teaching of $21^{\text {st }}$-century learners in Vocational Home Economics education. Journal of Educational and Social Research, 3(9), 105-108.

Baruah, B. K (2013). Agribusiness management, its meaning, nature and scope, type of management tasks and responsibility. www.assamagribusiness.nic.in/agriclinic/agribuness\%2o management.

Egbiri, J. W., \& Chukwuedo, S. O. (2013). Reengineering technical vocational education and training. Nigerian Vocational Association Journal (NVA), 18(1), 74-82.

Ejinkeonye, U. B. (2016). Enhancing the utilization of Information Communication Technology (ICT) among Home Economics lecturers in South-Eastern Nigeria. Journal of Education and Practice, 7(9), 34-39. 
Ejiofor, T., \& Nwakile, T. C. (2016). Revitalizing technical vocational education and training for job creation and national development through agricultural education programmes in tertiary institutions in Nigeria. Journal of Association of Vocational and Technical Educator of Nigeria (JAVTEN), 21(2), 102-110.

Federal Republic of Nigeria (2013). National Policy on Education. Lagos: NERDC.

Guma, A., Faruque, A. H., \& Khushi, M. (2013). The role of ICT to make teaching and learning effective in higher institutions of learning in Uganda. International Journal of Innovative Research in Science Engineering and Technology. An ISO certified Organization. http//wwwijirset.com/upload/ august .67. the \% 20 role PDF. Retrieved on $2^{\text {nd }}$ April 2019.

Iyere, F. O., \& Orunwense, F. E. (2007). Towards the enlargement of clothing and textiles education in schools. Journal of Home Economics Research, 8, 74-79.

Joe, A. I. (2019). How relevant are Nigerian state universities today in teaching, research and scholarship? Convocation Lecture delivered at the $13^{\text {th }}$ Convocation ceremony of Delta State University, Abraka, Delta State, Nigeria. Thursday, 16 May.

Jongour, I. U., Mohammed, A., \& Abba, A. H. (2008), Learning strategies in teaching science through information and communication technology (ICT). Journal of Science Teachers Association of Nigeria, 43(1\&2).

National Bureau of Statistics (NBS) (2016), Nigeria's Unemployment Rate: Abuja.

Okoh, P., \& Azonuche, J. E. D. (2010). The use of information and communication technology in the learning of Home Economics in tertiary institutions; A springboard for skill acquisition. Journal of Contemporary Issues in Vocational and Technical Education, 3(1), 20- 29.

Oviawe, J. I., \& Ojo, K. E. (2010). Importance of information and communication technology in technical and vocational education workplace skills acquisition. Multidisciplinary Journal of Research Development, 15(4), $41-48$.

Sadker, M. P., \& Sadker, D. M. (2003). Teachers school and society: New York, McGraw-Hill.

Udoh, O. A. (2010). Influence of teacher competence and availability of resources on the application of ICT to the teaching of physics in SSS. Multi-Disciplinary Journal of Research Development, 15(4), 33-40.

Uko-Aviomoh, E. E. (2006). Promoting entrepreneurship through food and nutrition education. Journal of Home Economics Research, 7, 89-96.

Uko-Aviomoh, E. E. (2007). Globalized home economics education and poverty alleviation in Nigeria. Journal of Home Economics Research, 8, 129-139.

World Bank (2013). Sub-Sahara crises sustainable growth. A long Perspective study. Washington, D. C. 